\title{
Seroprevalence of viral agents in vaquejada horses
}

\author{
Soroprevalência de agentes virais em equinos de vaquejada
}

\author{
Heider Irinaldo Pereira Ferreira', Cecília Calabuig², Pedro Augusto Cordeiro Borges'1, Ilanna Vanessa Pristo \\ de Medeiros Oliveira', Débora Alves de Carvalho Freire ${ }^{3}$, Eliana Monteforte Cassaro Villalobos ${ }^{4}$, Maria do \\ Carmo Custódio de Souza Hunold Lara ${ }^{4}$, Edviges Maristela Pituco ${ }^{4}$, Adriana Hellmeister de Campos Nogueira \\ Romaldini ${ }^{5}$, Elenice Maria Sequetin Cunha ${ }^{4}$, Eliana De Stefano ${ }^{6}$, João Marcelo Azevedo de Paula Antunes ${ }^{7 *}$ \\ 'Veterinarians, MSc. Hospital Veterinário Jerônimo Dix-Huit Rosado Maia, Universidade Federal Rural do Semiárido - UFERSA, \\ Mossoró, RN, Brasil \\ 2Biologist, Ph.D. Departamento de Biociências, Universidade Federal Rural do Semiárido - UFERSA, Mossoró, RN, Brasil \\ ${ }^{3}$ Biotechnologist, MSc. Departamento de Ciência Animais, Universidade Federal Rural do Semiárido - UFERSA, Mossoró, RN, \\ Brasil \\ ${ }^{4}$ Veterinarians, Ph.D. Instituto Biológico, São Paulo, SP, Brasil \\ ${ }^{5}$ Veterinary, MSc. Instituto Biológico, São Paulo, SP, Brasil \\ ${ }^{6}$ Biologist, MSc. Instituto Biológico, São Paulo, SP, Brasil \\ `Veterinary, Ph.D. Hospital Veterinário Jerônimo Dix-Huit Rosado Maia, Universidade Federal Rural do Semiárido - UFERSA, \\ Mossoró, RN, Brasil
}

\begin{abstract}
In order to investigate the prevalence of viral diseases in vaquejada horses, samples were collected from Quarter Horse and Paint Horse breeds (males and females, aged between 2 and 15 years) from rural and urban areas of Mossoró, Rio Grande do Norte, Brazil were collected. The number of samples collected and tested varied with the techniques used: 132 serum samples were tested for vesicular stomatitis (VS) and equine viral arteritis (EVA), 118 for western and eastern equine encephalomyelitis (WEE/EEE), 114 for equine herpesvirus 1(EHV-1), and 61 for equine influenza (EI). The techniques used varied according to the disease studied: tests for VS (Ribeirão and Alagoas strains), EVA, EHV-1, and WEE/EEE were performed using the seroneutralization technique in Vero cell cultures, while the test for for EI type-2 (H3N8) was performed using the hemagglutination inhibition technique. The following results were obtained: 39 (29.55\%) and 6 (4.54\%) VS-positive horses ( $\mathrm{n}=132$ ) harbored the Alagoas and Ribeirão strains, respectively; no animal tested positive for EVA ( $n=132) ; 11.01 \%(n=13)$ and $0.84 \%(n=1)$ animals tested positive for EEE and WEE (total n=118), respectively; and 22 out of 114 (19.29\%) horses tested positive for EHV-1. The history of respiratory and reproductive diseases was statistically significantly $(p=0.02)$ related to the presence of antibodies against EHV-1. This is the first report of the seroprevalence of viral diseases in vaquejada horses in Rio Grande do Norte.
\end{abstract}

Keywords: antibodies, equine, Mossoró, vaquejada, viruses.

\section{Resumo}

Com o objetivo de pesquisar doenças virais em equinos de vaquejada foram coletadas amostras das raças Quarto de Milha e Paint Horse, machos e fêmeas, com idade variando entre 2 e 15 anos, criados nas zonas rural e urbana do município de Mossoró, Rio grande do Norte, Brasil. O número de amostras coletadas e testadas variaram durante a realização das técnicas: 132 amostras de soro foram testadas para estomatite vesicular (EV) e arterite viral equina (AVE), 118 para encefalomielite leste e oeste (EEL/EEO), 114 para herpesvírus tipo 1 (HVE-1) e 61 para influenza equina (IE). As técnicas utilizadas variaram de acordo coma enfermidade pesquisada: EV (cepas virais Ribeirão e Alagoas), AVE, HVE-1 eEEL/EEO foram pesquisados pela técnica de soroneutralização em culturas de células da linhagem Vero; enquanto a pesquisa para IE tipo-2 (H3N8) foi realizada pela técnica de inibição da hemaglutinação. Foram obtidos os seguintes resultados: 39 (29,55\% cepa Alagoas) e 6 (4,54\% cepa Ribeirão) de equinos positivos para EV ( $\mathrm{n}=132)$ nenhum animal positivo para AVE ( $n=132$ ), EEL/EEO ( $n=118$ ) com positividade de $11,01 \%$ ( $n=13)$ e $0,84 \%(n=1)$ respectivamente; e 22 (19,29\%) de equinos positivos para HVE-1 (n=114). Quanto às variáveis, histórico de doenças respiratórias e reprodutivas, as mesmas foram estatisticamente significativas ( $\mathrm{p}=0.02$ ) em relação à presença de anticorpos contra HVE-1. Este é a primeira descrição de soroprevalência de enfermidades virais em equinos de vaquejada no estado do Rio Grande do Norte, Brasil.

Palavras-chave: anticorpos, equinos, Mossoró, vaquejada, vírus.

\section{BJ $\mathrm{M}$}

Brazilian Journal of Veterinary Medicine

p-ISSN 0100-2430

How to cite: Ferreira H. I. P., Calabuig C., Borges P. A. C., Oliveira I. V. P. M., Freire, D. A. C., Villalobos E. M. C., Lara M.C.C.S.H., Pituco E. M., Romaldini A. H. C. N., Cunha E. M. S, DeStefano E., \& Antunes, J. M. A. P. (2018). Seroprevalence of viral agents in vaquejada horses. Brazilian Journal of Veterinary Medicine, 40, e54218. doi: 10.29374/2527-2179.bjvm057218

\section{Financial support: UFERSA.}

Conflict of interests: No conflict of interests declared concerning the publication of this article.

Received: February 2, 2018

Accepted: September 26, 2018

The study was performed out at Centro de Pesquisa em Saúde Animal, Instituto Biológico, São Paulo, SP, Brasil.

\section{*Correspondence}

João Marcelo Azevedo de Paula Antunes Hospital Veterinário Jerônimo Dix-Huit Rosado Maia, Universidade Federal Rural do Semiárido - UFERSA

Av. Francisco Mota, 572, Presidente Costa e Silva

CEP 59625-900 - Mossoró (RN), Brasil

E-mail: joao.antunes@ufersa.edu.br

Copyright Ferreira et al. This is an Open Access article distributed under the terms of the Creative Commons Attribution Non-Commercial License which permits unrestricted non-commercial use, distribution, and reproduction in any medium provided the original work is properly cited. 


\section{Introduction}

The equine herd of Brazil was estimated by the Instituto Brasileiro de Geografia e Estatística (IBGE) at 5,363,185 heads, and a large part of this (1,788,190 [28.7\%]) has been bred or maintained in the Northeast of the country, including the state of Rio Grande do Norte, with a total of 44,454 horses; and the municipality of Mossoró-RN, with a total of 1,121 horses (Instituto Brasileiro de Geografia e Estatística, 2013). The equine herd in Brazil involves more than 30 segments, distributed among inputs, and horses used for breeding, transportation purposes, agricultural activities, livestock management, leisure, sports, and equine therapy, forming the basis of the so-called Agro-Horse Complex, responsible for the generation of 3.2 million direct and indirect jobs; the rapid evolution of the socioeconomic importance of Brazilian equideoculture has increased interest and investment in equine medicine and the major diseases (Araripe, 2010).

Due to the regional peculiarities, and ecological and sanitary aspects, the few epidemiological studies that evaluated infectious diseases in horses in Brazil have presented divergent results regarding the prevalence, mainly in relation to viral diseases, which play an important role from a health and economic point of view, including: vesicular stomatitis (VS), viral arteritis, herpesvirus infections, encephalomyelitis, and influenza (Aguiar et al., 2008).

The VS virus affects horses; cattle; swine; and other mammals, including humans (Acha \& Szyfres, 1986). The etiological agent of VS belongs to the order Mononegavirales, family Rhabdoviridae, and genus Vesiculovirus. The major serotypes are New Jersey (VSNJV) and Indiana (VSIV), which include the Indiana 2 (VSIV-2), Cocal (COCV), and Indiana 3 (VSIV-3) groups. The prototype of this group is the Alagoas virus (VSAV). In Brazil, the disease is of sufficient importance to require immediate obligatory notification of any suspected case. There are reports of VS outbreaks in equines and cattle, in properties in the states of Ceará, Paraíba, and Rio Grande do Norte (Cargnelutti et al., 2014). These data indicate that SV is endemic in some regions, caused mainly by VSAV and sporadically by VSIV-2, including the strain 79RibeirãoE, isolated from an equine in 1979 in Ribeirão Preto, São Paulo (Pauszek et al., 2011). There are no records of the disease caused by VSNJV or VSIV serotypes. It is noteworthy that the majority of the VS virus infections are inapparent, and only 10-15\% of the animals present clinical signs, with mortality being rare.

Equine viral arteritis (EVA), caused by an RNA virus of the Arteriviridae family and genus Arterivirus (Braga et al., 2012), is widely distributed around the world and can affect horses, mules, donkeys, and zebras (Góngora et al., 2014). Equine herpesvirus (EHV) is a DNA virus belonging to the family Herpesviridae, and both EHV-1 and EHV-4 are endemic in the world equine population (Ma et al., 2013). Equine viral encephalomyelitis can be caused by three different types of RNA viruses of the Togaviridae family, of the genus Alphavirus: eastern (EEE), western (WEE), and Venezuelan equine encephalomyelitis (VEE) (Casseb, 2010). Equine influenza (EI) is a contagious and zoonotic disease caused by an RNA virus of the Orthomyxoviridae family, caused by the H7N7 and H3N8 subtypes (Oliveira et al., 2005; Office Internationaldes Epizooties, 2015).

Due to the scarcity of studies in relation to viral diseases in horses used in vaquejada, a sport that involves agglomeration of animals in a small space, favoring the horizontal transmission of diseases, this work aimed to investigate the seroprevalence of viral agents (VS, EI, equine encephalomyelitis, EHV, and EVA). The knowledge of the prevalence of these viruses in vaquejada horses will help design control measures for epidemiological surveillance.

\section{Material and methods}

This study covered the properties of vaquejada in the municipality of Mossoro (050 11 ' 15 "S, 370 20' 39" W), Rio Grande do Norte, Brazil. The inclusion criteria were: males and females of only the Quarter Horse and Paint Horse breeds, aged between 2 and 15 years, reared in rural and urban areas, and not vaccinated against the diseases that were surveyed. The study was approved by the Ethics Committee on the Use of Animals of the Federal Rural Semiarid University (protocol no.: 23091.005304/2015-81).

The municipality of Mossoró is divided into 5 regions (central, south, north, east, and west), with divisions including rural areas of the Caatinga Biome, and with a total of 1,121 (Instituto Brasileiro de Geografia e Estatística, 2013). These 5 regions of Mossoró include 40 rural properties with vaquejada horses. Twenty-two of these rural properties included 5, 5, 4, 4, and 4 from the central, east, north, west, and south regions, respectively. In these 22 farms, there were 242 animals; 
from these, 132 (54.54\%) representative samples of the 5 regions were collected. During the collection, the complete list of risk factors was applied: race; sex; age; rural or urban location; abortion; gestation time; practice for and frequency of matches per month (for males); monthly frequency of vaquejada trips; contact with wild animals; cohabitation with cattle; grazing in forested areas; and clinical characteristics with respect to respiratory, reproductive, neurological, skin, and mucosal diseases.

The samples were collected between July and August 2015 (post-rains period), with a concomitant physical examination of each animal. A total of 132 samples were collected by puncturing the jugular vein with disposable needles and vacuum tubes, and these samples were refrigerated until arriving at the clinical laboratory of the Veterinary Hospital of Federal Rural Semiarid University, where samples were centrifuged at $3000 \times g$ to obtain the sera. These were aliquoted in micro-tubes and stored at $-20^{\circ} \mathrm{C}$. The samples were then sent to the Biological Institute of São Paulo, São Paulo, to perform the diagnostic tests.

A total of 132, 118, 114, and 61 equines were tested for antibodies against VS virus and EVA, EEE/WEE, EHV-1, and EI. During the freezing and thawing process to perform the different tests, some samples were considered unsuitable and not tested. Therefore, all the tests were not performed for the same number of animals. The analysis of the samples and the technique used varied according to the disease studied; antibodies to VS virus (Ribeirão and Alagoas strains), EVA, EHV-1, and EEE/WEE were investigated using the seroneutralization technique in Vero cell culture, while the test for EI type-2 (H3N8) was performed using the hemagglutination inhibition technique.

Statistical analysis was performed to correlate the presence of antibodies against the diseases studied and the respective risk factors using a chi-squared test with cross-tabulations (non-parametric data). For these analyses, the statistical program SPSS version 22 (IBM Corp., Armonk, NY, USA) was used. The level of significance used was $\alpha=0.05$.

\section{Results and discussion}

The results regarding the seroprevalence are summarized in Table 1 . The number of samples collected and tested varied across techniques because the laboratories of the Biological Institute of São Paulo did not classify some of the suitable serum samples. According to OIE (Office Internationaldes Epizooties, 2012), possible sources of variation in results include: sampling, storage conditions, extraction methods, volumetric manipulation, analyst, equipment, contamination, and environmental conditions.

In the present study, none of the animals were found to be serologically positive for EVA, which was also observed by Cunha et al. (2009) and Heinemann et al. (2002), who studied the presence of viruses in Equidae from the Curitiba/PR, Uruará/PA, and southern regions of São Paulo, respectively. However, equine studies conducted in the same states have also reported seropositivity for EVA (Fernandes \& Souza, 1999; Lara et al., 2003), suggesting a non-homogeneous behavior in the epidemiology of the disease. Although vaquejada is an activity involving agglomeration and proximity of animals, which theoretically favors the transmission of the virus by the respiratory route, the results suggest that the EVA virus is not circulating in the population of vaquejada horses in this region.

The presence of antibodies against VS virus observed in the horses tested in this study corroborates the findings of Cargnelutti et al. (2014), who reported outbreaks of VS in horses

Table 1. Soroprevalence of viral agents of vaquejada horses, Mossoró, RN.

\begin{tabular}{lcc}
\hline \multicolumn{1}{c}{ Diseases } & Positives \% & n \\
\hline Vesicular Stomatitis (Alagoas) & $39(29.55 \%)$ & 132 \\
Vesicular Stomatitis (Ribeirão) & $6(4.54 \%)$ & 132 \\
Equine Viral Arteritis & $\mathrm{O}(0 \%)$ & 132 \\
Eastern equine encephalomyelitis & $13(11.01 \%)$ & 118 \\
Western equine encephalomyelitis & $1(0.84 \%)$ & 118 \\
Equine Herpevirus-1 & $22(19.29 \%)$ & 61 \\
Equine Influenza (H3N8) & $34(55.74 \%)$ & 614 \\
\hline
\end{tabular}


and cattle in the states of Paraíba and Rio Grande do Norte, where the affected horses in the city of Umarizal/RN had a history of participating in a vaquejada event 20 days prior to the visit and animals with clinical manifestation were included. In the present study, although $29.55 \%$ of the animals tested positive, none of them presented clinical signs in the study period. This frequency of occurrence shows that the VS is endemic to the region, supporting the findings of Cunha et al. (2009). According to Aguiar et al. (2008), VS shows seasonal incidence, occurring mainly after rainfall in regions with tropical climate, suggesting transmission of the disease by hematophagous insects, thus relating this affirmation to the findings of the present study, where samples were collected after the rainy season. Antibodies against the strain 79RibeirãoE were present in 4.54\% of the animals tested in this study, which has not been described in any study in the Northeast region. The relevance of this finding is further increased by the fact that infection by this strain of VS virus has only been diagnosed in the State of São Paulo (Pauszek et al., 2011), emphasizing the importance of epidemiological surveillance during the importation of animals from other states. Moreover, VS virus can occasionally affect humans and could be transmitted to other species of domestic and wild animals (Oliveira et al., 2018).

The frequency of antibodies to EEE (11.01\%) detected in the present study was lower than that found by Melo et al. (2012) in Mato Grosso (35.5\%), Cunha et al. (2009) in the south of São Paulo (16\%), and Heinemann et al. (2006) in Pará (27\%). Our results demonstrate circulation of the virus in the region and some EEE outbreaks, as described by Silva et al. (2011) in municipalities of Paraíba, Ceará, and Pernambuco, suggesting that the disease is related to average temperature, rainfall, and other environmental factors of the semi-arid climate that determine the density of the vectors. None of the previous studies included animals with a history of neurological symptomatology, studying only the animal's contact with the virus but not the development of the disease. The prevalence of antibodies to EEW observed in the present study (0.84\%) was similar to that found by Heinemann et al. (2006), who reported values of 1.2\% in the Pantanal regions of Mato Grosso and southern Pará, also showing low viral circulation.

In this study, the prevalence of antibodies against EI type H3N8 was $55.74 \%$, higher than that found by Heinemann et al. (2009) in Pará (76.5\%) and Mancini et al. (2014), who reported a prevalence of 97.2\% of antibodies against H3N8 in São Paulo; Oliveira et al. (2005) reported a prevalence of 35.9\% in Rio de Janeiro. These high indexes suggest the ease of transmission of the virus in equine populations, mainly where there is agglomeration of animals and EI transmission occurs through the respiratory route.

The prevalence of antibodies to EHV-1 detected in this study (19.09\%) is very close to those reported by Aguiar et al. (2008) in Rondônia (22.7\%), Heinemann et al. (2006) of in Pará (17\%), and Cunha et al. (2009) in São Paulo (26\%), although Araripe et al. (2010) reported a prevalence of $41.2 \%$ in the metropolitan area of Fortaleza/CE. This diversity of findings across several states suggests that the virus is distributed throughout the country, as reported by Cunha et al. (2009). The relationship between the history of respiratory disease and the number of animals testing positive for EHV-1 was statistically significant $\left(\chi^{2}=7.7, \mathrm{p}<0.05, \mathrm{df}=1.36\right.$; Table 2$)$, a fact already reported by Soriano et al. (1997), who reported that 36\% of the EHV-1-positive animals exhibited respiratory symptoms. There was a statistically significant difference $\left(\chi^{2}=8.9, \mathrm{df}=1.29, \mathrm{p}<0.05\right.$; Table 3) between the history of reproductive diseases and the number of animals testing positive for EHV-1. However, Marcolongo-Pereira et al. (2012) and Schlafer (2004) have reported that

Table 2. Relation of history of respiratory disease with EHV-1.

\begin{tabular}{lcccc}
\hline & & \multicolumn{2}{c}{ Respiratory Disease } & Total \\
\cline { 3 - 4 } & & $\mathbf{0}$ & $\mathbf{1}$ & \\
\hline EHV-1 & 0 & $7_{\mathrm{a}}$ & $9_{\mathrm{b}}$ & 16 \\
& 1 & $1_{\mathrm{a}}$ & $19_{\mathrm{b}}$ & 20 \\
Total & & 8 & 28 & 36 \\
\hline
\end{tabular}

Each subscript letter indicates a subset of the variable "respiratory disease" categories whose column ratios do not differ significantly from each other at the 0.05 level (O for negative and 1 for positive). 
Table 3. Relation of history of reproductive disease with EHV-1

\begin{tabular}{lcccc} 
& & \multicolumn{2}{c}{ Reproductive Disease } & Total \\
\cline { 3 - 4 } & & $\mathbf{0}$ & $\mathbf{1}$ & \\
\hline EHV-1 & 0 & $19^{\mathrm{a}}$ & $2^{\mathrm{b}}$ & 21 \\
& 1 & $3^{\mathrm{a}}$ & $5^{\mathrm{b}}$ & 8 \\
Total & & 22 & 7 & 29 \\
\hline
\end{tabular}

Each subscript letter indicates a subset of the varable "reproductive disease" categories whose column ratios do not differ significantly from each other at the 0.05 level ( $\mathrm{O}$ for negative and 1 for positive).

viral infection is of minor importance as a cause of abortion in horses in the southern region, probably due to the use of vaccines. In our study, a frequent transit of animals was observed and vaccination was not performed, which may have favored the association of reproductive problems and positivity for EHV-1.

\section{Conclusion}

The results suggest that the EVA virus is not present among the vaquejada horses in Mossoró, Rio Grande do Norte, Brazil. We found evidences of the prevalence of other viruses (EHV-1, and those causing VS, EI, EEE, and WEE), and the animals testing positive for these can transmit the respective diseases in the equine populations used in vaquejada, an activity that favors agglomeration of animals and people. Considering that most of these viruses can affect both equines and humans, health education measures should be implemented to control vectors and zoonoses, and thus ensure better human and animal health, and environmental conditions.

\section{References}

Acha, N. P., \& Szyfres, B. Estomatitis vesicular, p.388-393. In: Acha, N.P. \& Szyfres, B. Zoonosis y enfermidades transmisibles comunes al hombre y a los animales. 2.ed. Washington: editora, 1986.

Aguiar, D. M., Cavalcante, G. T., Lara, M. D. C. C. S. H., Villalobos, E. M. C., Cunha, E. M. S., Okuda, L. H., Stéfano, E. D., Nassar, A. F. C., Souza, G. O., Vasconcellos, S. A., Labruna, M. B., Camargo, L. M. A., \& Gennari, S. M. (2008). Prevalência de anticorpos contra agentes virais e bacterianos em equídeo s do município de Monte Negro, Rondônia, Amazônia ocidental brasileira. Brazilian Journal of Veterinary Research and Animal Science, 45(4), 269-276. http://dx.doi.org/10.11606/issn.1678-4456.bjvras.2008.26685.

Araripe, M. G. A. (2010). Detecção sorológica do herpesvírus equídeo (EHV-1, EHV-4) e parâmetros hematológicose bioquímicos de equinos utilizados em vaquejada (Dissertação de mestrado). Universidade Estadual do Ceará, Fortaleza.

Braga, P. R. C., Lara, M. C. C. S. H., Dias, A., Cunha, E. M. S., Villalobos, E. M. C., Ribeiro, M. G., \& Borges, A. S. (2012). Soroprevalência da arterite viral equina em mesorregiões paulistas entre 2007e 2008. Semina, 33, 1501-1506.

Cargnelutti, J. F., Olinda, R. G., Maia, L. A., Aguiar, G. M. N., Neto, E. G. M., Simões, S. V. D., Lima, T. G., Dantas, A. F. M., Flores, R. W. E. F., \& Riet-Corrêa, F. (2014). Outbreaks of Vesicular stomatitis Alagoas virus in horses and cattle in northeastern Brazil. Journal of Veterinary Diagnostic Investigation, 26(6), 788-794. http://dx.doi. org/10.1177/1040638714553428. PMid:25274744.

Casseb, A. R. (2010). Soroprevalência de anticorpos e padronização do teste elisa sanduíche indireto para 19 tipos de arbovírus em herbivoros domésticos (Tese de doutorado). Universidade Federal do Pará, Belém.

Cunha, E. M. S., Villalobos, E. M. C., Nassar, A. F. C., Lara, M. C. C. S. H., Peres, N. F., Palazzo, J. P. C., Silva, A., Stéfano, E., \& Pino, F. A. (2009). Prevalência de anticorpos contra agentes virais em equídeos no sul do estado de São Paulo. Arquivos do Instituto Biológico, 76, 165-171.

Fernandes, W. R., \& Souza, M. C. C. (1999). Determinação sorológica da arterite viral equina em equinos hígidos, com abortamento e com sintomas de alteração do sistema respiratório. Revista Brasileira de Ciência Veterinária, 6(3), 147-150. http://dx.doi.org/10.4322/rbcv.2015.156.

Góngora, A., Barrandeguy, M., \& Ciuderis, K. (2014). Monitoreo serológico de arteritis viral equina en municipios de la Orinoquia, Colombia. Revista Mvz Cordoba, 19, 4269-4276. http://dx.doi.org/10.21897/rmvz.89.

Heinemann, M. B., Cortez, A., Lara, M. C. C. S. H., Cunha, E. M. S., Nassar, A. F. C., Villalobos, E. M. C., Ferreira Neto, J. S., Homem, V. S. F., \& Ferreira, F. (2009). Soroprevalência do vírus da influenza equina no município de Uruará, PA, Brasil, Amazônia oriental. Arquivos do Instituto Biológico, 76, 697-699. 
Heinemann, M. B., Cortez, A., Souza, M. C. C., Gotti, T., Ferreira, F., Homem, V. S. F., Ferreira Neto, J. S., Soares, R. M., Sakamoto, S. M., Cunha, E. M. S., \& Richtzenhain, L. F. (2002). Soroprevalência da anemia infecciosa equina, da arterite viral dos equinos e do aborto viral eqüino no município de Uruará, PA, Brasil. Brazilian Journal of Veterinary Research and Animal Science, 39(1), 50-53. http://dx.doi.org/10.1590/S1413-95962002000100009.

Heinemann, M. B., Cortez, A., Souza, M. C. C., Gotti, T., Ferreira, F., \& Homem, V. S. F. (2006). Soroprevalência da encefalomielite eqüina do leste e oeste no Município de Uruará, PA, Brasil. Brazilian Journal of Veterinary Research and Animal Science, 43(Suppl.), 137-139. http://dx.doi.org/10.11606/issn.1678-4456.bjvras.2006.26546.

Instituto Brasileiro de Geografia e Estatística. (2013). Pesquisa Pecuária Municipal. Rio de Janeiro: IBGE. Retrieved in 2015, September 6, from http://cidades.ibge.gov.br

Lara, M. C. C. S. H., Barros Filho, I., Viana, F., Gregory, L., Cunha, S. E. M., \& Castro, A. F. (2003). Pesquisa de anticorpos contra o vírus da arterite dos equinos (VAE) e herpes equino tipo-1 (HVE-1) em cavalos criados em Curitiba, PR. A Hora Veterinária, 23, 51-53.

Ma, G., Azab, W., \& Osterrieder, N. (2O13). Equine herpesviruses type 1 (EHV-1) and 4 (EHV-4) masters of co-evolution and a constant threat to equids and beyond. Veterinary Microbiology, 167(1-2), 123-134. http:// dx.doi.org/10.1016/j.vetmic.2013.06.018. PMid:23890672.

Mancini, D. A. P., Pereira, A. S. P., Mendonça, R. M. Z., Kawamoto, A. H. N., Alves, R. C. B., Pinto, J. R., Mori, E., Richtzenhain, L. J., \& Mancini-Filho, J. (2014). Presence of respiratory viruses in equine in Brazil. Revista do Instituto de Medicina Tropical de São Paulo, 56(3), 191-195. http://dx.doi.org/10.1590/s0036-46652014000300002. PMid:24878995.

Marcolongo-Pereira, C., Adrien, M. L., Ladeira, S. R. L., Soares, M. P., Assis-Brasil, N. D., \& Schild, A. L. (2012). Abortos em equinos na região Sul do Rio Grande do Sul: estudo de 72 casos. Pesquisa Veterinária Brasileira, 32(1), 22-26. http://dx.doi.org/10.1590/S0100-736X2012000100005.

Melo, R. M., Cavalcanti, R. C., Villalobos, E. M. C., Cunha, E. M. S., Lara, M. C. C. S. H., \& Aguiar, D. M. (2012). Encefalomielites e anemia infecciosa no estado de Mato Grosso. Arquivos do Instituto Biológico, 79(2), 169175. http://dx.doi.org/10.1590/S1808-16572012000200004.

Office Internationaldes Epizooties. (2012). Vesicular Stomatitis: Manual of Diagnostic Tests and Vaccines for Terrestrial Animals (Chap. 2.1.19). Paris: OIE. Retrieved in 2015, December 10, from http:// www.oie.int/Eng/ normes/mmanual/A_index.htm

Office Internationaldes Epizooties. (2015). Animal disease information. Paris: OIE. Retrieved in 2015, September 7, from http://www.oie.int

Oliveira, A. M., Fonseca, A. A., Camargos Junior, M. F., Orzil, L. M., Laguardia-Nascimento, M., Oliveira, A. G. G., Rodrigues, J. G., Sales, M. L., Oliveira, T. F. P., \& Melo, C. B. (2018). Development and validation of rt-qpcr for vesicular stomatitis virus detection (Alagoas vesiculovirus). Journal of Virological Methods, 257, 7-11. http:// dx.doi.org/10.1016/j.jviromet.2018.03.011. PMid:29601843.

Oliveira, G. S., Schiavo, P. A., Mazur, C., \& Andrade, C. M. (2005). Prevalência de anticorpos para o vírus da Influenza Eqüina, subtipo H3N8, em equídeos apreendidos no estado do Rio de Janeiro. Ciência Rural, 35(5), 1213-1215. http://dx.doi.org/10.1590/S0103-84782005000500038.

Pauszek, S. J., Barrera, J. C., Goldberg, T., Allende, R., \& Rodriguez, L. L. (2011). Genetic and antigenic relationships of vesicular stomatitis viruses from South America. Archives of Virology, 156(11), 1961-1968. http://dx.doi. org/10.1007/s00705-011-1081-1. PMid:21830071.

Schlafer, D. H. (2004). Postmortem examination of the equine placenta, fetus and neonates: methods and interpretation of indings. Proceedings of American Association of Aquine Practitioners, 50, 144-157.

Silva, M. L. C. R., Galiza, G. J. N., Dantas, A. F. M., Oliveira, R. N., Iamamoto, K., Achkar, S. M., \& Riet-Corrêa, F. (2011). Outbreaks of Eastern equine encephalitis in northeastern Brazil. Journal of Veterinary Diagnostic Investigation, 23(3), 570-575. http://dx.doi.org/10.1177/1040638711403414. PMid:21908293.

Soriano, B. M. A., Oliveira, H. D. E., Catto, J. B., Comastri, J. A. F., Galdino, S., \& Salis, S. M. (1997). Plano de utilização da fazenda Nhumirim (Vol. 21, 72 p., Documento). Corumbá: Centro de Pesquisa Agropecuária do Pantanal - EMBRAPA. 